\title{
Gestational Trophoblastic Neoplasm Clinical TNM Finding v8
}

National Cancer Institute

\section{Source}

National Cancer Institute. Gestational Trophoblastic Neoplasm Clinical TNM Finding v8. NCI Thesaurus. Code C140016.

A clinical finding about one or more characteristics of a gestational trophoblastic neoplasm, following the rules of the TNM AJCC v8 classification system. 